前庭導水管の拡大を伴った感音難聴の 2 症例

瀬成田雅光・西川 典秀・原晃

草杊潤・黒崎 喜久*

\title{
Large Vestibular Aqueduct Syndrome Associated with Sensorineural Hearing Loss ; A Report of Two Cases
}

\author{
Masamitsu Senarita, Norihide Nishikawa, Akira Hara, \\ Jun Kusakari and Yoshihisa Kurosaki
}

(University of Tsukuba)

We report two cases of large vestibular aqueduct syndrome, which was first described by Valvassori and Clemis in 1978. A 12-year-old female and a one-year-old male presented with bilateral profound hearing loss. Auditory evoked brainstem response was performed in the latter case, but no reproducible wave was recorded bilaterally. High-resolution axial CT of the temporal bone revealed markedly enlarged vestibular aqueducts bilaterally in the former case and unilaterally in the latter. No significant anomaly was found in any other part of the temporal bone on CT scans.

The possible etiology of sensorineural hearing loss in this syndrome is discussed, and the available literature is reviewed.

Key words: large vestibular aqueduct syndrome, sensorineural hearing loss, CT

はじめに

内耳奇形は先天性竩あるいは幼児期に発見さ れる高度難聴の原因として重要であり，様々な タイプに分類されている.1978年 Valvassori ら 1)が多軌道断層撮影を用い, 前庭導水管(VA) の拡大を示すものを large vestibular aqueduct syndrome(LVAS) として報告して以来, 内耳 奇形の独立した 1 型として認識され, 感音難聴 との関連が注目されている. 我々も本疾患と思 われる 2 症例を経験したので文献的考察を加え 報告する。

\section{症例}

症例 1.12 歳, 女性.

主訴 : 両側難聴・右耳鳴.

家族歴 : 父方祖父が幼児期より両側高度難聴 があったとのことであるが，詳細は不明である。 近親婚なし。

既往歴：3 歳時までは特に気付かれなかった が， 3 歳頃会話の時に耳を傾けてくるため近医 を受診したところ，䆍に近い左難聴を指摘され た. その 6 カ月後, 4 歳時に突然右の難聴が出 現し, 突発性難聴の診断で投薬を受け, 聴力は 約 $40 \mathrm{~dB}$ に改善した. 7 歳時より右耳に補聴 
器を使用し, 読唇法の併用で普通学級に通い, 日常生活上も支障はなかった。

現病歴：1984年 3 月25日突然右の難聴および 耳鳴が出現し，その 3 日後より 37 度台の発熱と 両耳の圧迫感が出現したため近くの耳鼻咽喉科 を受診し，4月 2 日より15日までステロイド漸 減療法, ウロキナーゼによる点滴治療を受けた が改善せず，当科紹介され 4 月 17 日入院となっ た。

入院時現症 : 身長 $151 \mathrm{~cm}$, 体重 $43 \mathrm{~kg}$, 栄養 状態良好. 耳介, 外耳, 鼓膜は正常で, 頭頸部 その他全身にも異常所見を認めなかった。 入院 時の純音聴力検査を図 1 亿示す。平衡機能検査 では偏倚, 立ら直り反射正常, 自発拈よび注視 眼振検査でも異常を認めなかったが，温度眼振 検査では左無反応, 右も反応が減弱していた。 また指標追跡検査, 視運動性眼振検査は正常で あった。

検査成績 : 血液・生化学的検査ではいずれも 異常なく，血沈も正常であった。CRP， RA， TPHA はいずれも陰性で，ASO も正常範囲内 であった。ウイルス抗体価はムンプス，アデノ, 風疹，麻疹，HSV，VZV，EBVにつきペア血 清にて測定したが，いずれも有意の変動を認め

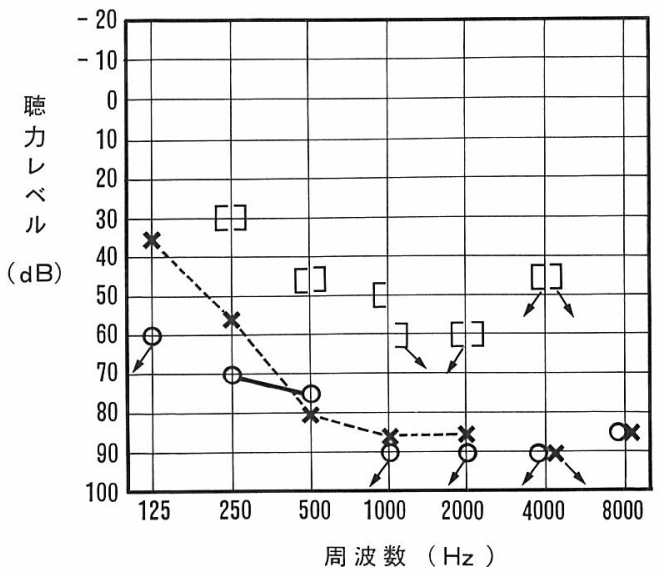

図 1 入院時の聴力 症例 1
なからた。

入院後経過：ステロイド漸減，ATP，プロス タグランディン $\mathrm{E}_{1}$ による点滴治療を 12 日間行 ったところ耳鳴は改善したが，聴力は不変であ った

CT 所見：両側の VA の拡大を認めた（図 2， 3 ).この前後を $1.5 \mathrm{~mm}$ 幅で撮影したが，蝸 牛, 前庭, 半規管の骨迷路には異常を認めなか った。

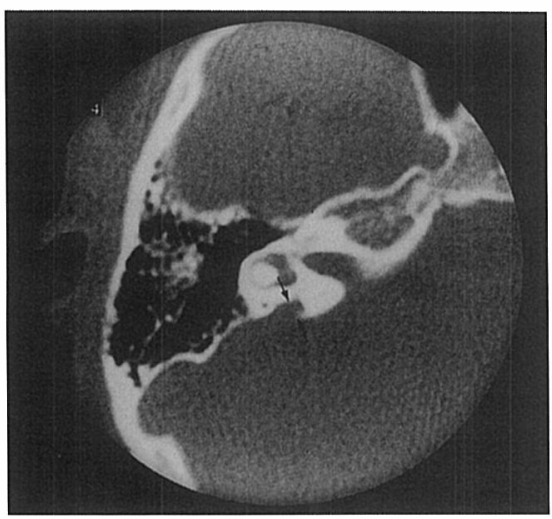

図 2 症例 1 ．右軸位 $\mathrm{CT}(\mathrm{OM}+17 \mathrm{~mm})$ VA の外口の幅(矢印)は $5 \mathrm{~mm}$ であり拡大 を認める。

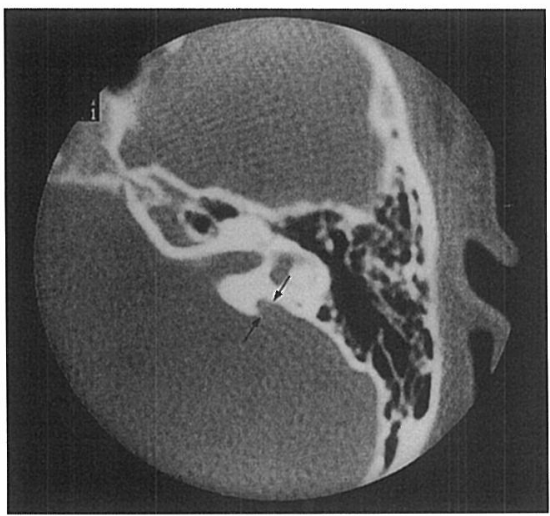

図 3 症例 1 ．左軸位 $\mathrm{CT}(\mathrm{OM}+19 \mathrm{~mm})$ VA の外口の幅(矢印)は $5 \mathrm{~mm}$ であり拉大 を認める。 
症例 2. 1 歳 6 力月, 男性.

主訴：音に反応しない。

既往歴：特記すべきことなし。

家族歴：特記すべきことなし，近親婚なし。

現病歴：1990年初め頃両親が音に反応しない ことに気付き, 某大学病院を受診し聴性脳幹反 応 $(\mathrm{ABR})$ を施行されたが，両耳とも無反応， また耳単純 $\mathrm{X}$ 線検査にて内耳の形成不全を疑わ れた。両親の都合により当県での検査, 治療を 望又 4 月 7 日当科初診となった。

初診時所見：鼓膜所見は両側鼓膜の軽度陥凹 を認める以外は正常. その他耳鼻咽喉扣よび全 身に発育障害や異常を認めなかった。

検查所見 : 幼児聴力検查では聴力障害は 110

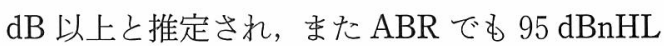
の刺激にても無反応であった。

CT 所見：両側の滲出性中耳炎と, 右 VAの

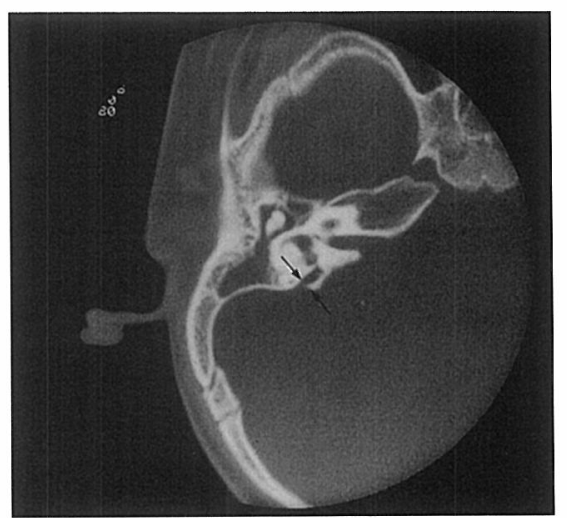

図 4 症例 2 . 右軸位 $\mathrm{CT}(\mathrm{OM}+18 \mathrm{~mm})$ $\mathrm{VA}$ の外口の幅(矢印) は $4 \mathrm{~mm}$ であり拡大を 認める．上鼓室から乳突洞は軟部組織陰影で 占められ含気は認められない。
拡大を認めた(図 4 )。症例 1 同様, 蝸牛, 前庭, 半規管の骨迷路には異常を認めなかった。

\section{考察}

1978年 Valvassori ら ${ }^{1)}$ は3700例に対し内耳 の多軌道断層撮影を行い, 50 例(約1.5\%) そVA の拡大を認め，これを large vestibular aqueduct syndrome (LVAS) と名付けた. その特徵 として彼らは，(1)VAの拡大(VAの狭部以後 の中点, あるいは外口と総脚の中点に抢いて前 後径が $1.5 \mathrm{~mm}$ 以上)の他に，(2)約 $60 \%$ で前庭 の桩大など他の内耳奇形を合併すること，(3)ほ とんどの例で先天性あるいは幼少時からの聴力 障害を伴らこと，(4)家族内発生が稀であること， (5)前庭に奇形を合併していても前庭障害は稀で あることなどをあげている。

1980年代に入り高分解能 CT が側頭骨にも導 入され，内耳の奇形をかなり詳細に描出できる ようになり，CTによる本疾患の報告も増えて きている(表 1 )。これらの報告症例と我々の 2 症例を対比させながら本疾患の特徵, 問題点等 を中心に考察を加光たい。

1) VA の拡大について

VA そその内部に内リンパ管と内リンパ垶 (ES)の近部拉よび中間部の一部を入れる骨管 で，前庭の内側壁より起こり半規管の総脚と平 行に上後方に走り, ESの中間部付近より後下 方へ屈曲し後頭蓋窩に開口している2)(図 5 ). その解剖については側頭骨を用いた研究で諸家 により報告されている. Ogura ら² によるヒト 正常耳16例の検討ではVA は平均して長さが $8.7 \mathrm{~mm}$, 太さは最も狭い狭部で $0.3 \mathrm{~mm}$, 最も 太い外口で $6.2 \mathrm{~mm}$ でめったとしている。また 江上ら ${ }^{4)}$ は再構築画像を使いVA に様々な破格

表 1 CT による large vestibular aqueduct syndrome の報告

\begin{tabular}{|c|c|c|c|c|c|}
\hline 報告者 & 年度 & 例数 & スライス幅 & 撮影面 & VA 拡大の基準 \\
\hline Hill 5 & 1984 & 1例 2 耳 & $1 \mathrm{~mm}$ & 軸位 & \\
\hline Swartz 5 & 1985 & 3例 3耳 & $1.5 \mathrm{~mm}$ & 軸位·矢状断 & 最大径 $2 \mathrm{~mm}$ 以上 \\
\hline Levenson 5 & 1989 & 12例 22耳 & $1.5 \mathrm{~mm}$ & 軸位 & 外口径 $2 \mathrm{~mm}$ 以上 \\
\hline
\end{tabular}


があると報告している. 従ってLVAS の基準 として CT 上の撮影面・VA 拡大の部位・拡大 幅が問題となるが，今日をでLVASの明確な 基準を示した報告は少ない. その理由として, もともとVAのX線所見が注目されるように なったのは1968年に Clemis と Valvassori ${ }^{5)}$ が メニェール病患者でのVA の描出率が低いこ とを報告したのが最初であり, 以後メニエール 病とVA の関連についての報告は多数あるも のの拡大についてはあまり注目されなかったこ と, 近年までVAの評価が断層撮影によって なされてきたこと，VAが図 5 のごとく弯曲し て走行しているので, 側頭骨で一般的に使用さ れる軸位 CT のみではその全体像をとらえるの が困難なことなどがあげられてきた。しかし近 年, 表 1 に示すごとくCT による LVAS の基準 を示す報告も散見されてきている. LVAS の基 準として Swartz ら ${ }^{6)}$ は軸位 CT でVA の最大 径が $2 \mathrm{~mm}$ 以上を, Levenson ら ${ }^{7)}$ は同じく軸 位 CT で外口の幅が $2 \mathrm{~mm}$ 以上をLVAS とし ている.これらの基準に従えば, 我々の症例に おいても外口の幅が症例 1 では左右とも $5 \mathrm{~mm}$, 症例 2 の右耳が $4 \mathrm{~mm}$ であり LVAS と考えて 良いと思われた. 更に最近ではVA外口の観 察にCT の 3 次元再構成画像を用いた報告もあ り8), より詳細に生体での VAの評価を行らこ とが可能となってきている.

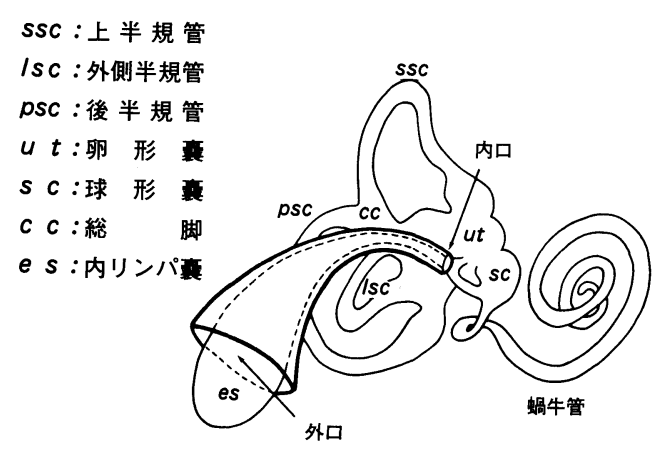

図 5 VAのシェーマ

(Schuknecht HF, et al : 198622 より改変)
2 ) 他の内耳奇形の合併について

Valvassori ら ${ }^{1)}$ はVASの約 $60 \%$ VAの 拡大以外の内耳奇形の合併を認めたことより, LVAS の原因を胎生期の内耳発育の停止と推 測した。特に Jackler ら ${ }^{9110)}$ は胎生 5 週から 8 週に扮いて起こるVAの縮小過程の障害とし ている．合併する奇形の中では前庭の拡大が最 も多く，その他に半規管の拡大や蝸牛の低形成 などが認められている116)。一方, 先天性感音 難聴のらちX線学的に奇形を認めるのは約 $20 \%$ とされているが7), 膜迷路の奇形についての情 報を得ることは今日の画像診断の技術をもって しても困難なことが多い. Kodama ら ${ }^{11) 12)}$ は, 再構築画像を使った検討により，VAに含まれ る部分の内リンパ管や ES の大きさはVA に比 例していると考兄て良いと報告している，しか しVAの拡大が蝸牛や前庭の膜迷路の形態や 機能異常と関係があるのか否かを推測すること は困難である.今回の症例 2 の左耳のよらに $\mathrm{CT}$ 上は特に異常を認めないのに高度の感音難 聴が存在する例もあり，また逆にVAの拡大 を認めたにもかかわらず難聴の存在しない例も 報告されて抢り ${ }^{13)}$, 膜迷路の異常を伴らものと 伴わないものが存在すると推測される.このこ とから LVAS は “画像診断学的にVA が拡大 しているもの”と定義して抢くのが適当ではな いかと考えている.

3 ）難聴の合併について

VA の拡大は両側性あるいは一側性に認めら れるが，多くの報告ではVAの拡大している 側に感音難聴が合併している11677)10113114)。その 多くは先天性あるいは幼児時に気付かれた中等 度〜高度の感音難聴で, その聴力型は必ずしも 一定しない様である. Levenson ら7) は小児の LVAS の検討の結果, VA が拡大しているもの は聴力が正常であっても軽い頭部外傷などが原 因で突然の難聴を生じることがあり，これは拡 大した ES が脳脊髄液の圧を受けやすく, 蝸牛 方向に内リンパの逆流を生じるためであろらと 推察している. 症例 1 の右耳では 2 度突然の難 
聴を来して拉り，彼らの推論を支持するものか もしれない。

4 ) 平衡機能について

Hill ら 14) はめまいを伴ら LVAS の 1 例を報 告し, LVAS は内耳の形態上の異常のみなら ず，聴覚平衡系の機能異常をも含むものである と結論つけたた。たValvassori ら1) も50例の LVAS のらち 6 例に平衡機能検査を行ったと ころ全ての例で反応の欠如あるいは反応低下を 認め, 怙そらく全例で機能異常が存在するでめ ろらとしている. 前述した如く，今日に至るも 膜迷路の形態を明確に診断することは困難であ る. 従って, その機能異常を聴覚, 平衡の諸機 能検査の結果で推測せざるを得ない，この意味 で平衡機能検査は重要であると考えられる. 症 例 1，2 ともにめまいの既往はなかったが, 症 例 1 では温度眼振検查で右反応低下, 左無反応 といら結果であり, 何らかの膜迷路の障害が示 唆された，症例 2 は幼少のためまだ施行できな いが，今後検討を加えていく所存である.

\section{結語}

内耳奇形はその後の言語修得の観点からも早 期に発見し，最善の対策を立てることが重要で ある. 我々はVA の拡大を伴った高度感音難 聴の 2 症例を経験したので報告し, 併せて文献 的に考察を加えた。

尚, 本文の要旨は第18回日本臨床耳科学会 (大分) にてロ演発表した。

\section{文 献}

1) Valvassori GE and Clemis JD: The large vestibular aqueduct syndrome. Laryngoscope $88: 723 \sim 728,1978$.

2) Schuknecht HF and Gulya AJ : Anatomy of the Temporal Bone with Surgical Implications. pp 136, Lea \& Febiger, Phiradelphia, 1986.

3) Ogura $\mathrm{Y}$ and Clemis JD : A study of the gross anatomy of the human vestibular aqueduct. Ann Otol Rhinol Laryngol 80 : 813 825, 1971.

4）江上徹也, 山藤勇: 前庭水管の Graphic
Reconstruction. 日耳鼻 82 : 895 898, 1979.

5) Clemis JD and Valvassori GE : Recent radiographic and clinical observations on the vestibular aqueduct. Otolaryngol Clin North Am 1 : 339 346, 1968.

6) Swartz JD, Yussen PS, Mandell DW, et al : The vestibular aqueduct syndrome ; computed tomographic appearance. Clin Radiol $36: 241$ $\sim 243,1985$.

7) Levenson MJ, Parisier SC, Jacobs M, et al : The large vestibular aqueduct syndrome in children. Arch Otolaryngol Head Neck Surg $115:$ 54 58, 1989.

8) Yamamoto $\mathrm{E}$, Mizukami $\mathrm{C}$, Isono $\mathrm{M}$, et al : Observation of the external aperature of the vestibular aqueduct using three-dimensional surface reconstruction imaging. Laryngoscope $101: 480 \sim 483,1991$.

9) Jackler RK, Luxford WM and House WF : Congenital malformation of the inner ear; a classification based on embryogenesis. Laryngoscope $97: 2 \sim 14,1987$.

10) Jackler $\mathrm{RK}$ and Cruz ADL : The large vestibular aqueduct syndrome. Laryngoscope $99:$ 1238 1242, 1989.

11) Kodama A and Sando I : Postnatal development of the vestibular aqueduct endolymphatic sac. Ann Otol Rhinol Laryngol 91 Suppl $96: 3$ $\sim 12,1982$.

12) Kodama A and Sondo I : Dimensional anatomy of the vestibular aqueduct and the endolymphatic sac in human temporal bone. Ann Otol Rhinol Laryngol 91 Suppl 96 : 13 20, 1982.

13) Emmett JR : The large vestibular aqueduct syndrome. Am J Otol 6 : 387 403, 1985.

14) Hill JH, Freint AJ and Mafee MF : Enlargement of the vestibular aqueduct. Am J Otol 5 : 411 414, 1984.

\footnotetext{
(原稿受付: 平成 4 年 9 月 2 日 原稿採択: 平成 4 年 9 月 15 日 別刷請求先 : 原 晃 干305つくば市天王台1-1-1 筑波大学臨床医学系耳鼻咽喉科学教室
} 